\title{
A Novel Approach for investigation of Morphological and Biochemical Characterization of Sunflower through different treatments
}

Ebadet Ali $^{1}$, Syed Asad Raza Shah Naqvi ${ }^{2}$, Asif Ali $^{3}$, Hafiza Maria Mahmood ${ }^{2}$, Maria Rafiq ${ }^{4}$, Anam Ejaz ${ }^{5}$, Muhammad Shakil $^{2 *}$

${ }^{1}$ Department of Botany, Hazara University Mansehra, Pakistan

${ }^{2}$ Department Botany, University of Agriculture, Faisalabad Pakistan

${ }^{3}$ Department of Botany, University of Karachi, Pakistan

${ }^{4}$ Department Biochemistry, University of Agriculture, Faisalabad Pakistan

${ }^{5}$ Department of Zoology, Wildlife and Fisheries, University of Agriculture, Faisalabad Pakistan

DOI: $10.36348 /$ sb.2021.v07i04.002 $\quad$ | Received: 24.02.2021 | Accepted: 15.03.2021 | Published: 11.04 .2021

*Corresponding author: Muhammad Shakil

\section{Abstract}

Zinc as one of the heavy metals that influence of the growth of the plant. Its deficiency in plants leads to abnormal growth of roots cells that ultimately inhibited the RNA and proteins synthesis. Sunflower has gains much important in agricultural pint of view due to its morphological characteristics. High and low concentrations of the zinc have been evaluated on the different parameters of sunflower. Water in the concentrations of $25 \mathrm{ml}$ were applied carefully to the each pots and crops were harvested for evaluation of microbiological and morphological parameters such as for number of leaves of sunflower hybrids, root dry weight of sunflower, shoot dry weight of sunflower, chlorophyll pigments, carotenoids. In relation to biochemical attributes chlorophyll $a$ and chlorophyll $b$ were reduced while a subsequent elevation was observed in carotenoid. Maximum reduction of growth, biochemical and physiological parameters was noted at $40 \mathrm{mM}$ concentration of zinc. Zinc toxicity involves in inhibition of cytoplasmic enzymes and damage to cell structures due to oxidative stress. It alters the catalytic function of enzymes which damage the cellular membranes and inhibit root growth. Zinc stress cause maximum effect on hybrid FH674 as compared to other hybrid FH687.

Keywords: Sunflower, chlorophyll a, chlorophyll b, Carotenoids, Leaves, Stems.

Copyright (C) 2021 The Author(s): This is an open-access article distributed under the terms of the Creative Commons Attribution 4.0 International License (CC BY-NC 4.0) which permits unrestricted use, distribution, and reproduction in any medium for non-commercial use provided the original author and source are credited.

\section{INTRODUCTION}

Foliar application also promoted root absorption of the same or other plant nutrients by increasing growth of roots and uptake of nutrients. Foliar application was a successful method of nutrients supply during exhaustive periods of plant growth for the growth and crop yield. Foliar application of minerals like $\mathrm{Zn}, \mathrm{B}$, and $\mathrm{Fe}$ are considered more realistic as compared to soil application due to its adsorption with soil particles and lesser contact with the roots of crop. Recently, the application of micronutrients is extensively used both as broadcast and foliar for increasing the productivity of crops, therefore, application of micronutrients may need to be examined by the appropriate method and dosage for enhancing the seed and oil yield of sunflower[1-3].
Sunflower (Helianthus annuus L.) is one of the most popular members of the family Asteraceae and is one of the world's most important sources of vegetable oil. The native of the sunflower is reported to be Southern parts of USA and Mexico. Sunflower ranks third, next to groundnut and soybean in the total production of oilseeds in the world. Sunflower is cultivated on an area of 23.70 million hectares with an annual production and productivity of 31.33 million tonnes and $1322 \mathrm{~kg}$ per hectare, respectively in the world $[5,6]$.

This study aimed to access the microbiological and physiological studies of sunflower using integrative approach. It was carried out to access the different factors affecting on the growth of sunflower viz heavy metals that significantly reduced the growth. 
Ebadet Ali et al., Sch Bull, Apr, 2021; 7(4): 77-81

\section{MATERIALS AND METHODS \\ Plant materials}

Zinc sulphate $\left(\mathrm{ZnSO}_{4}\right)$ utilized as basic of zinc element. Three (0mM, 20mM and $40 \mathrm{mM}$ ) levels of $\mathrm{Zn}$ were applied to access the microbial and morphological parameters $[7,8,9]$. Hybrids of two sunflower varieties FH 687 and FH 674 were utilized for the research work and attained and 18 plastic pots were occupied with 8 $\mathrm{kg}$ soil [9-11]. The pots used for sowing contain an underneath hole which was covered by a piece of fine cotton cloth. Before sowing, pots were irrigated with tab water. Approximately 8 seeds were sown in each pot at the depth of $2 \mathrm{~cm}$. Healthy seeds of similar size were selected for sowing. The experiment strategy was factorial completely randomized strategy with three repetitions. Afterward propagation, plant were moistened with tap water whenever required. After germination, seedlings were thinned to maintain 4 plants per pot of equal size and then applied zinc to the plants to start my experiment [12-14].

\section{Treatments and Source}

Simple water used to treat plants and salt concentrations in a specific amount and make the solution in $1.5 \mathrm{~L}$ of water and apply to specific plants.

1- Normal water or $0 \mathrm{mM}$ zinc solution

2- $20 \mathrm{mM}$ zinc solution

3- 40mM zinc solution

\section{Germination}

8 seeds were sown in each pots and after 5 days seed were germinate all pots were totally germinate first 20 days simple water was applied after 20 days they were applied $\mathrm{ZnSO}_{4}$. Just one time metal applied in whole research to analyze and check the impact of heavy metal zinc sulphate $\left(\mathrm{ZnSO}_{4}\right)$ stress on two hybrids FH687 and FH674. Varying concentration of zinc sulphate $(0,20,40, \mathrm{Mm})$ with $250 \mathrm{ml}$ tap water was applied in rooting medium. On every day basis the $250 \mathrm{ml}$ water were applied to each pot. The crop was harvested after 45 days and check all the morphological parameters were studied Root length, Shoot length, Root weight, Shoot weight and number of leaves [15].

\section{Harvests}

Plants were harvested after 45 days of treatment and following parameters were studied.

\section{DATA COLLECTION}

Two plants from each pot were collected after applying treatment. Plants were pulled up cautiously and washed with tab water. Data for growth, physiological and microbiological parameters were recorded. Fresh weight noted immediately in lab then they were left in oven to study their dry weight and for further studies.
Parameters studies

For different growth constraints data was documented

\section{Growth parameters \\ Number of leaves}

By keeping the fresh samples in oven at $65 \mathrm{C}^{\circ}$ for 1 week to get constant dry weight and mean values were calculate [12].

\section{Shoot dry weight}

Dry weight of shoot were determined after keeping the fresh samples in oven at $65 \mathrm{C}^{\circ}$ for 1 week to get constant dry weight and mean values were calculate[16].

\section{Root dry weight}

Dry weight of root were determined after keeping the fresh samples in oven at $65 \mathrm{C}^{\circ}$ for 1 week to get constant dry weight and mean values were calculated[17,18].

\section{Photosynthetic pigments}

Method of Arnon was used for the determination of chlorophyll $\mathrm{a}$ and $\mathrm{b}$ and carotenoids contents. Leaf samples $(0.20 \mathrm{~g})$ were cut and left overnight in $10 \mathrm{ml}$ of $80 \%$ acetone. The next morning the extracts were centrifuged at $10,000 \mathrm{rpm}$ for $5 \mathrm{~min}$ and the supernatant's absorbance was recorded at 480, 645 and $663 \mathrm{~nm}$ using a spectrophotometer [19].

The following equations were used to determine the chlorophyll contents:

Chlorophyll $\mathrm{a}=[12.7$ (OD 663) - $2.69(\mathrm{OD}$ 645) $\mathrm{x}$ $\mathrm{V} / 1000 \times \mathrm{W}$

Chlorophyll $b=[22.9$ (OD 645) - 4.68 (OD663) $x$ $\mathrm{V} / 1000 \times \mathrm{W}$

$\mathrm{A}^{\mathrm{car}}=$ OD480+0.114(OD663)-0.638(OD645)

Carotenoids $=\mathrm{A}^{\mathrm{car}} / 2500 \times 100$

$\mathrm{V}=$ volume of the extract $(\mathrm{ml})$

$\mathrm{W}=$ weight of the fresh leaf tissue $(\mathrm{g})$

\section{RESULTS AND DISCUSSIONS}

Effect of zinc sulphate $\left(\mathrm{ZnSO}_{4}\right)$ on sunflower hybrids FH 687 and FH 674 on their development and physio-chemical traits, Results are given below as parameter wise.

\section{Number of leaves (per plant)}

Data for number of leaves of sunflower hybrids FH 687 and FH674 grown under control (T0=Water) condition and zinc sulphate $\left(\mathrm{ZnSO}_{4}\right)$ stress condition presented below in graph. Application of zinc sulphate stress caused a significant reduction in number of leaves. With increasing concentration of zinc in soil solution number of leaves reduced. Maximum reduction at $40 \mathrm{mM}$ (Water $+\mathrm{ZnSO}_{4} 40 \mathrm{mM}$ ) zinc sulphate was applied in rooting medium was observed as compared to control series. FH 687 show better growth than the hybrid FH 674. 


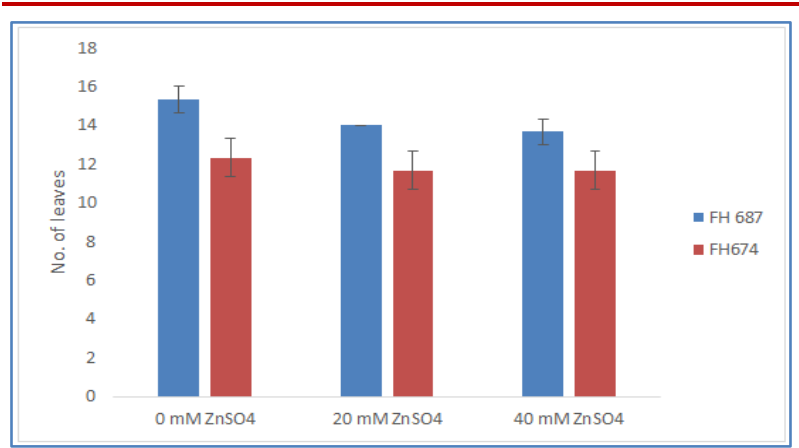

Fig-1: Shows the Number of leaves of two sunflower hybrids grown under zinc stress

\section{Root dry weight (g)}

Data for root dry weight of sunflower hybrids FH 687 and FH674 grown under control (T0=Water) condition and zinc sulphate $\left(\mathrm{ZnSO}_{4}\right)$ stress condition is presented below in graph. Application of zinc sulphate stress caused a significant reduction in root dry weight. With increasing concentration of zinc in soil solution root dry weight reduced. Maximum reduction at $40 \mathrm{mM}$ (Water $\left.+\mathrm{ZnSO}_{4} 40 \mathrm{mM}\right)$ zinc sulphate was applied in rooting medium was observed as compared to control series. FH 687 show better growth than the hybrid FH 674.

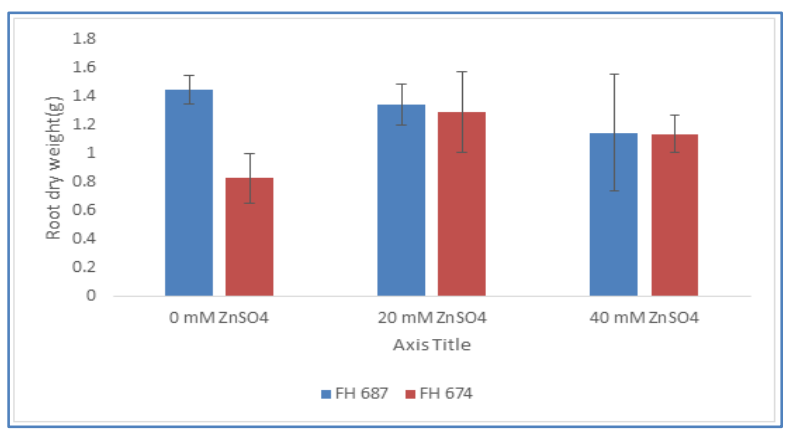

Fig-2: Shows the Root dry weight of two sunflower hybrids grown under zinc stress

\section{Shoot dry weight (g)}

Data for shoot dry weight of sunflower hybrids FH 687 and FH674 grown under control (T0=Water) condition and zinc sulphate $\left(\mathrm{ZnSO}_{4}\right)$ stress condition is presented below in graph. Application of zinc sulphate stress caused a significant reduction in shoot dry weight. With increasing concentration of zinc in soil solution shoot dry weight reduced.

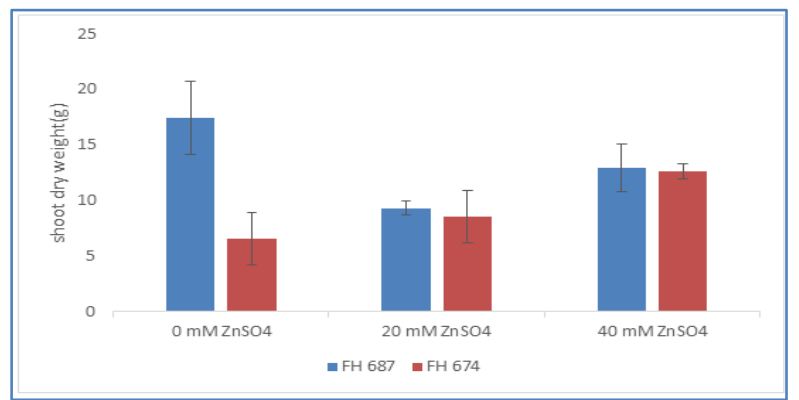

Fig-3: Shows the Shoot dry weight of two sunflower hybrids grown under zinc stress

\section{Chlorophyll a (mg/g fresh weight)}

Data for chlorophyll a of sunflower hybrids FH 687 and FH674 grown under control (T0=Water) condition and zinc sulphate $\left(\mathrm{ZnSO}_{4}\right)$ stress condition presented below in graph. Application of zinc sulphate stress caused a significant reduction in chlorophyll a. With increasing concentration of zinc in soil solution chlorophyll a reduced.

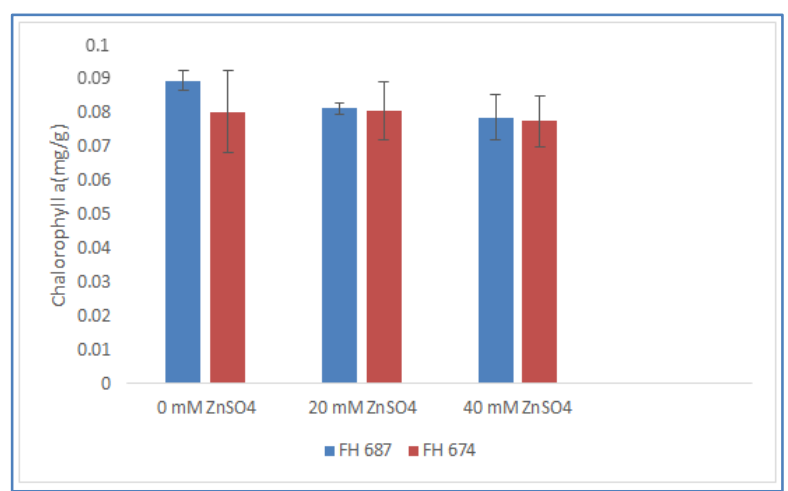

Fig-4: Shows the Chlorophyll a contents of two sunflower hybrids grown under zinc stress

\section{Chlorophyll b (mg/g fresh weight)}

Data for chlorophyll $b$ of sunflower hybrids FH 687 and FH674 grown under control (T0=Water) condition and zinc sulphate $\left(\mathrm{ZnSO}_{4}\right)$ stress condition is presented below in graph. Application of zinc sulphate stress caused a significant reduction in chlorophyll $b$. With increasing concentration of zinc in soil solution chlorophyll b reduced.

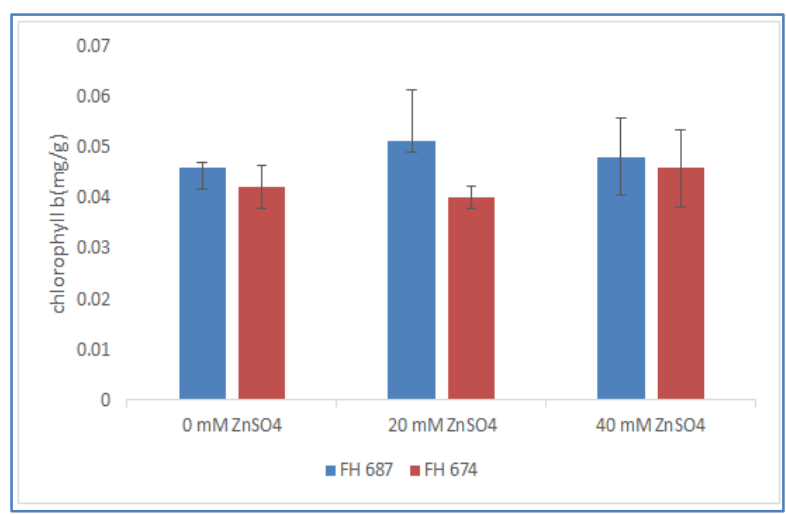

Fig-5: Shows the Chlorophyll b of two sunflower hybrids grown under zinc stress

\section{Carotenoids (mg/g fresh weight)}

Data for carotenoid of sunflower hybrids $\mathrm{FH}$ 687 and FH674 grown under control (T0=Water) condition and zinc sulphate $\left(\mathrm{ZnSO}_{4}\right)$ stress condition is presented below in graph. Application of zinc sulphate stress caused a significant reduction in carotenoid. With increasing concentration of zinc in soil solution carotenoid reduced. Maximum reduction at $40 \mathrm{mM}$ (Water $+\mathrm{ZnSO}_{4} 40 \mathrm{mM}$ ) zinc sulphate was applied was observed as compared to control series. FH 687 show better growth than the hybrid FH 674. 


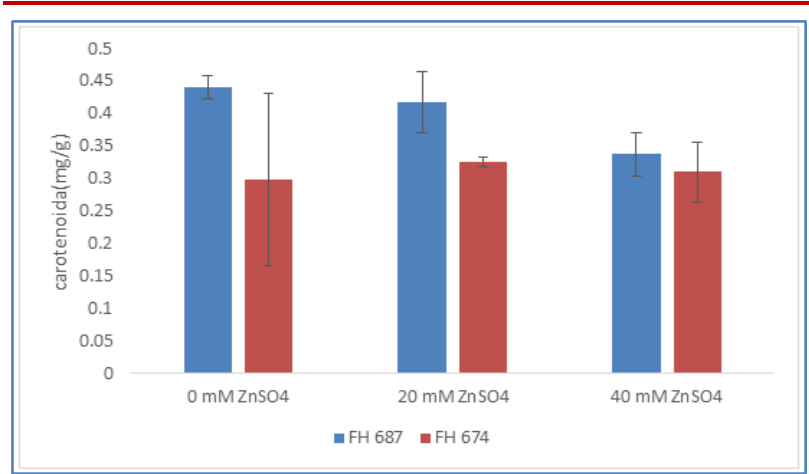

Fig-6: Shows the Carotenoid of two sunflower hybrids grown under zinc stress

Zn stress significantly reduced the growth attributes. Zinc is a microelement which should be taken in very less amounts by plants, animals and humans. In the deficiency of zinc, RNA levels and the cell's ribosome content decrease and this situation lead to a decrease in the protein formation mechanism. Besides, in deficiency of zinc in the plants, indexes of indol-3-acedic acid (IAA), abscisic acid and tryptophan amino acid levels also decreases. This situation gives damages to the normal growth of the plants and affects the herbal production in a serious way. The toxic effect of $\mathrm{Zn}^{2+}$ cause damages to the cell division and it especially gives damages to the cell nucleus of meristematic stem cell [18-20].

At the same time, $\mathrm{Zn}^{2+}$ stress results in chlorosis, which is defined as damage in the activity of chloroplast and shrinking of the plant's size. It also affects the productivity and decreases the amount of chlorophyll and resoluble proteins, the length of the root, the weight and the amount of the seed [21-23].

The most adverse effect of $\mathrm{ZnSO}_{4}$ on sunflower is chlorosis it is seem that after application of stress the sunflower become reduced their growth plant stem become weak and some plants were lay down. It is also observe that the zinc effect is most adversely on the plant root which were not penetrate well in the growing media all these aspects give us that the heavy metal zinc sulphate cause adverse effect on the plant health. Hybrid FH674 show greater reduction in their (root length, shoot length, shoot fresh, weight root. Fresh weight, shoot dry weight, root dry weight, chlorophyll a chlorophyll b carotenoid) as compared to hybrid FH687 [24].

\section{CONCLUSION}

Effect of heavy metal investigated to understand the toxic nature of zinc and their physiological behavior. The results indicated that greater reduction in their fresh, weight root, chlorophyll a chlorophyll b carotenoid in different varieties of sunflower. Zinc as heavy metal that significantly increases the growth of different parts of plants form one side while on the other hand, it also influence the reduction in different parts of plant at cellular and molecular level.

\section{ACKNOWLEDGEMENT}

This work especially acknowledges to Muhammad Shakil that actively particularly and run parameters for completion of this work. Muhammad Shakil has done has assist in organizing, shaping of the article for publication of this work.

\section{REFERENCES}

1. Shahid, A., Ali, S., Zahra, T., Raza, M., Shahid, A., Saeed, M. U., \& Javaid, F. Influence of Microbes in Progression of Cancer and DNA Damaging Effects.

2. Iftikhar, A., Shahid, A., Shah, S. S., Ali, S., Raza, M., Ali, E., \& Umbreen, S. Antimicrobial Activities of Selected Medicinal Plant with Potential Role of Chemical Compounds.

3. Qamar, M., Mustafa, G. A., Tariq, S., Rafeeq, H., Rafiq, M., Naqvi, W. Z., \& Kanwal, T. Novel Methods for Detection of Biological Samples, Current Direction and Future Perspectives.

4. Munns, R., Day, D. A., Fricke, W., Watt, M., Arsova, B., Barkla, B. J., \& Tyerman, S. D. (2020). Energy costs of salt tolerance in crop plants. New Phytologist, 225(3), 1072-1090.

5. Naeem, M., Hayat, M., Qamar, S. A., Mehmood, T., Munir, A., Ahmad, G., \& Hussain, A. (2019). Risk factors, genetic mutations and prevention of breast cancer. Int. J. Biosci, 14(4), 492-496.

6. Alexander, M. (1978). Introduction to soil microbiology. Soil Science, 125(5), 331.

7. Peng, L., Hua, Y., Cai, J., Zhao, J., Zhou, W., \& Zhu, D. (2014). Effects of plants and temperature on nitrogen removal and microbiology in a pilotscale integrated vertical-flow wetland treating primary domestic wastewater. Ecological engineering, 64, 285-290.

8. Shafiq, S., Adeel, M., Raza, H., Iqbal, R., Ahmad, Z., Naeem, M., \& Azmi, U. R. (2019). Effects of Foliar Application of Selenium in Maize (Zea Mays L.) under Cadmium Toxicity. In Biological Forum-An International Journal, 11(2), 27-37).

9. Ahmad, I., Khan, S., Naeem, M., Hayat, M., Azmi, U. R., Ahmed, S., \& Irfan, M. (2019). Molecular Identification of Ten Palm Species using DNA Fingerprinting. Int. J. Pure App. Biosci, 7(1), 4651.

10. Usman, G., Muhammad, N., Hamza, R., Usman, I., Ayesha, A., Saqib, U., \& Fatima, Q. (2019). A Novel Approach towards Nutraceuticals and Biomedical Applications. Scholars International Journal of Biochemistry, 2(10), 245-252.

11. Tahir, M. F., Ali, S., Noman, M., \& Goher, M. A Novel Approach towards the Potential Effects of Chlorpyrifos on Testicular Biochemistry and Physiology of Male Sprague Dawely Rats. 
12. Naeem, M., Ali, J., Hassan, M. Z., Arshad, B., Rao, M. H. I., Sarmad, M. S. K., ... \&amp; Hassan, M. U. (2019). Novel Approach towards DNA Barcoding as a Tool in Molecular Biologyand Biological Activities of Cyclotides with Particular Emphasizes at Molecular Level. In Biological Forum-An International Journal, 11(2), 83-96.

13. Naeem, A., Saddique, S., \& Chand, S. A. (2019). Advancement and Future Directions towards Herbal Treatment for Various Diseases.

14. Naeem, M., Ashraf, A., Safdar, H. M. Z., Khan, M. Q., Rehman, S. U., Iqbal, R., \& Ahmad, G. (2020). Biochemical changes in patients with chronic kidney failure in relation to complete blood count and anemia. IJB, 16(1), 267-271

15. Naeem, M., Hussain, A., Azmi, U. R., Maqsood, S., Imtiaz, U., Ali, H., \& Ghani, U. (2019). Comparative Anatomical Studies of Epidermis with Different Stomatal Patterns in Some Selected Plants Using Compound Light Microscopy. International Journal of Scientific and Research Publications, 9(10), 375-380.

16. Ahsan, M., Aslam, M., Akhtar, M. A., Azmi, U. R., Naeem, M., Murtaza, G., \& Shafiq, S. (2019). Effect of inoculation of three rhizobial strains on maize hybrids. Journal of Biodiversity and Environmental Sciences, 14(6), 168-177.

17. Hazafa, A., Batool, A., Ahmad, S., Amjad, M., Chaudhry, S. N., Asad, J., \& Ghani, U. (2020). Humanin: A mitochondrial-derived peptide in the treatment of apoptosis-related diseases. Life Sciences, 264, 2021, 118679.

18. Khan, S., Abbas, A., Ali, I., Arshad, R., Tareen, M. B. K., \& Shah, M. I. (2019). Prevalence of overweight and obesity and lifestyle assessment among school-going children of Multan, Pakistan.

19. Rafeeq, H., Ahmad, S., Tareen, M. B. K., Shahzad, K. A., Bashir, A., Jabeen, R., \& Shehzadi, I. Biochemistry of Fat Soluble Vitamins, Sources, Biochemical Functions and Toxicity. Haya: The Saudi Journal of Life Sciences

20. Ghani, U., Naeem, M. Bukhari, S.S.H., Yar, G., Tariq, I., Siddique, S., Nawaz, H.A., Pal, Z.A.A., Nasim, F., \& Bukhari, S.A.H. (2019). Prevalence and Risk Factors associated with Hepatitis B and Hepatitis C and their Correlation with Inflammatory Markers among Southern Region of Punjab. Biological Forum - An International Journal, 11(2): 136-143.

21. Khan, S., Zelle Rubab, S. H., Abbas, A., Arshad, R., \& Tareen, M. B. K. Hematological profile of children with severe acute malnutrition at the Tertiary care hospital in Multan.

22. Muhammad, N., Umair, R.A., Sarmad, A.Q., Ahmad, M., Tariq, M., Muhammad, A. F. (2019). Reliable vaccine production by using Risk Based Bioengineering Strategies. 6th International Conference on "Sustainable Agriculture in Changing Climate: Strategies and Management. 261.

23. Rafeeq, H., Arshad, M. A., Amjad, S. F., Ullah, M. H., Muhammad, H., Imran, R. K., ... \& Ajmal, H. Effect of Nickel on Different Physiological Parameters of Raphanus Sativus.

24. Salvat, A., Antonnacci, L., Fortunato, R. H., Suárez, E. Y., \& Godoy, H. M. (2001). Screening of some plants from Northern Argentina for their antimicrobial activity. Letters in applied microbiology, 32(5), 293-297. 